\title{
EVOLUTION OF SOCIO-PHILOSOPHICAL APPROACHES TO MERCY IN THE CONTEXT OF SOCIAL DEVELOPMENT
}

\author{
Yuriy Khodanych \\ Department of Philosophy \\ Uzhhorod National University \\ 3 Narodna sq., Uzhhorod, Ukraine, 88000 \\ yurahodanych@gmail.com
}

\begin{abstract}
The article is devoted to the study of the evolution of socio-philosophical approaches to charity in the context of social development. The author analyzes the phenomenon of mercy through the prism of various philosophical traditions and views: Confucianism and the period of Antiquity, the Middle Ages (Blessed Augustine), German classical philosophy, Russian religious philosophy, Western philosophical thought of the twentieth century, neo-Marxism and post-Marxism. The author comes to the conclusion that at different periods of the socio-philosophical thought development, the understanding of mercy is different and receives a variety of interpretations: charity, love for neighbors, altruistic love-agape, the manifestation of the subject's activity in the context of social practice, etc. Mercy appears as an inner motive based on compassion, sacrifice, and active participation in the needs of others. Moreover, the value of mercy permeates all religious trends, defining the role of a person in his/her interaction with all others. At the present stage of development, mercy can be considered as an element of the social ethics of responsibility (of the individual for the natural and social environment of his/her activity), and also serves as a factor in the active participation of individuals in self-organizing self-government, the formation of civil associations with the aim of implementing reforms in society.
\end{abstract}

Keywords: mercy, social practice, charity, love for the neighbor, social exclusion.

\section{Introduction}

The current situation demonstrates that a person of the XXI century «suffers» from indifference and exclusion from society. Among the reasons for these, it is possible to single out globalization processes and the establishment of pragmatism in various spheres of society's life. All this contributes to the fact that the individual as a member of society is «closed» to the problems of other members of society, he/she focuses on their own interests and needs. As a result, we observe the lack of openness to other people. The abovementioned suggests the necessity of finding and developing forms of rapprochement between people, establishing and developing mercy, compassion, and other forms of leveling off with other members of society. The stated phenomena in the modern world allow overcoming social exclusion and indifference of people to each other, to help others, to experience their problems and to participate in their solution. Thus, the significance of the phenomenon of mercy in today's conditions of social development lies in its powerful integration potential, which implies the possibility of ignoring own selfish interests to the benefit of another person as an individual. In this way, mercy is an important alternative to the modern processes of asserting individualism and social exclusion.

Taking into consideration the interdisciplinarity of the research topic (social philosophy, axiology, ethics, religious studies, etc.), the theoretical principles for the justification of the phenomenon of mercy rely on various philosophical traditions and concepts. First of all, these include the views of thinkers belonging to different epochs in the context of the historical and philosophical thought development: Confucius, Mo-tzu, Plato, Aristotle, Cicero, Seneca [1], Aurelius Augustine $[3,4]$, representatives of the German classical philosophy (I. Kant [5, 6], G. V. F. Hegel, L. Feuerbach [7]). The spiritual basis of mercy in I. Kant and G. V. F. Hegel presents the commandment of love for his neighbor, based on the general requirement of humanity. In L. Feuerbach, mercy is based on the sense of love (the activity of the sensory heart), and the very essence of man is related to the ability to suffer and participate in the happiness of another.

F. Nietzsche considered phenomenons of compassion and mercy as manifestations of the «morals of slaves», the weak, instead, the «moral of the lords» was associated with the ethics of love for a far-fetched, based on the will of power as the main instinct of the right of the strong. 
The phenomenon of mercy is considered through the prism of Russian religious philosophy by V. Solovyov, F. Dostoevsky, L. Tolstoy, M. Berdyaev, P. Florensky, S. Frank, M. Lossky. Here mercy is based on the Christian virtue of love (to God and neighbor) and appears as a duty of the believer, turned to the other. Through the manifestation of mercy there is an affirmation of the individuality (dignity) of each and the connection in the divine.

Separately, the phenomenon of mercy can also be viewed through the prism of the "philosophy of the heart»: B. Pascal, H. Skovoroda, P. Yurkevych, B. Vysheslavtsev, M. Scheler. In this sense it is possible to analyze mercy through the prism of the phenomenon of the «heart» as the spiritual center of personality, the concentration of his soul and the relationship with God and the neighbor.

At the present stage of social development, the significance and realization of the phenomenon of mercy correlates with the ideas of neo-Marxism (G. Lukács, A. Gramsci, H. Marcuse, E. Bloch, H. Lefebvre, L. Althusser, W. Benjamin and others) and post-Marxism (E. Mandel, O. Lafontaine, I. Mészáros, F. Feher, A. Gorz, R. Scholz, H. Reichelt and others). The significance of these directions is that mercy can be considered here through the prism of modern social development in various spheres of society's life (political, economic, spiritual etc.). In particular, the realization of mercy is one of the manifestations of a person's moral responsibility for his/her environment.

\section{The aim of research}

To reveal the nature of the phenomenon of mercy through the prism of socio-philosophical approaches to its understanding in the context of social development.

\section{The main socio-philosophical approaches to mercy}

The phenomenon of mercy became the subject of philosophical reflection in the ancient period of socio-philosophical thought development. The period is presented by Confucianism and the era of Antiquity. In particular, through the prism of Confucianism (Confucius, Mo-Tzu), benevolence («Ren») appears to be the spiritual and moral foundation of mercy, which inevitably relates to the nobility of the spirit, courage, observance of a ritual, a sense of dignity and respect for another person. The ancient Greek tradition formed the idea of love-agape (merciful one). According to Plato, love is associated with the pursuit of beauty, well-being and immortality. From Aristotle's point of view, mercy is associated with the notions of moral virtues, deeds and aspirations for happiness.

A significant approximation to the nature of the phenomenon of mercy is observed in the works of the Roman stoic philosopher Seneca («Moral Letters to Lucilius» and «On Benefits»). Beneficence is considered by Seneca as a goal for itself: a person, performing benevolent deeds for another person, does not expect anything in return, that is, he/she performs them unselfishly: «beneficence is done for the sake of beneficence» [1]. The very essence of beneficence (based on the wording of this concept) implies an act for good or an act whose purpose is good. In this sense, beneficence may be regarded as synonymous with mercy.

Proceeding from the analysis of Seneca's work «On Benefits», several elements of the very beneficence should be singled out: (others);

1) the subject of beneficence, that is, the one who gives, sacrifices, assists another person

2) the object of beneficence is another person (others), that is, people to whom the act of benefiting is performed;

3) the matter of beneficence is the very gift or help, carried out in different ways in favor of another person;

4) the act of beneficence is directly bestowing benefits on another person.

Seneca highlights several «rules» of benefiting:

1) it is worth performing beneficence in the way that we would like them to be done in our favor, - with joy, quickly and without any doubt (hesitations);

2) it is worthwhile to do kindness before it is asked for; 
3) «the law of benefiting»: the one who did beneficence, should not talk about it, and the one who received it, on the contrary, should speak about benefits bestowed on him/her [1]. Therefore, on the one hand, we deal with the selflessness of benefiting, but on the other hand - about the gratitude for it;

4) it is worth doing charity in favor of a worthy person, which is the result of a certain search and choice on the side of the subject of beneficence; otherwise, beneficence in favor of the unworthy person «cannot be neither virtue nor beneficence» [1]. Consequently, the subject of beneficence must be conscious of when, to whom and for what purpose to perform the act of benefiting.

The conceptions of mercy in the Middle Ages were associated with the development of Christianity. Here mercy comes from God through Jesus Christ, according to his example of life, which should take place between people. Aurelius Augustine associated mercy with compassion, forgiveness, and highlighted its two aspects: emotional and practical ones. Mercy itself is based on love (for God and for the neighbor). Aurelius Augustine highlighted two aspects of mercy: an emotional one that lies in one's compassion to fellowmen, and concrete practical one, that lies in forgiveness and beneficence [2, p. 225]. He defines mercy as «a kind of compassion of our heart to someone else's misfortune - compassion that makes us provide all possible assistance. Such (hearty) movement obeys the mind when mercy is manifested with the preservation of justice: when the assistance is provided to those in need or the forgiveness is given to those who repent» $[3$, p. 378$]$.

In Blessed Augustine's «Confessions», mercy is perceived as one of the most important attributes of God. God's mercy appears as the all-seeing and gentle attitude of God to man, his creation. Such mercy is comforting and compassionate [4, p. 472]. When God shows mercy to man, this results in the pity for man and further forgiveness of his sins.

The ideas of the representatives of German classical philosophy are important for the understanding of the phenomenon of mercy. In particular, according to I. Kant, the source of mercy in the ethical dimension should be found in the notion of moral duty. A person acts not only as a goal in itself, but also as a «legislator» of his/her will in his/her face (for himself/herself), as well as on a universal scale. In its turn, the universal moral law, having at the same time the meaning for each individual separately, originates from the «idea of the intelligent creature's dignity, who obeys only the law that they simultaneously prescribe themselves» [5, p. 276]. I. Kant calls «benefiting» the duty of every person, that is, «whenever possible, to help people and to promote their happiness without hoping to receive a certain reward in turn». At the same time, the philosopher notes that by their «benefiting» people should not evoke the sense of duty in another person, in order not to humiliate their neighbor, instead, they should «pretend that they themselves are obliged or consider it the honor for themselves the fact that another person accepted this benefaction» [6, p. 393-394]. In other words, one should not take his/her own charity as a merit or as an object for praise.

According to L. Feuerbach (the work «The Essence of Christianity»), mercy is closely linked with the concepts of love, compassion, and most importantly-sensuality («only sensuous beings can be merciful» because people «are endowed with flesh and blood»). Mercy appears as the «moral law of sensuality», it is a manifestation of the heart, and the very heart «manifests itself in love». God, as merciful, is not an abstract God, but sensual as a person («human God»), since he is capable of feeling human pain, suffering, capable of compassion. Moreover, «God became man out of mercy: thus, he was in himself already a human God before he became an actual man; for human want, human misery, went to his heart» [7, p. 64-65]. God, therefore, as an incarnated person (Jesus Christ as the sensual essence of God) has a he art, and therefore is capable of compassion, is able to forgive sins and to sympathize with a person. Turning to God for mercy, a person, is as if appealing to himself/herself (to his/ her heart), seeking comfort there [7, p. 71]. The essence of a person is directly associated by L. Feuerbach with the ability to feel suffering and compassion for one's neighbor, to accept other people's suffering («to sympathize with, to experience another person's sufferings means to be a human») [7, p. 337-338]. Moreover, another person appears also as a necessary precondition for self-awareness and self-cognizing. 
Mercy in the context of Russian religious philosophy (V. Solovyov, M. Berdyaev, F. Dostoevsky, L. Tolstoy, P. Florensky, S. Frank, M. Lossky) is based on the Christian virtue of love (for God and for the neighbor) and appears as the duty of the believer which is turned toward another person. The affirmation of the individuality (dignity) of each person and the reunion in the divine is performed through the manifestation of mercy. In particular, M. Berdyaev calls merciful love «Caritas» (love-pity). This kind of love «does not need anything for itself, it gives to others", and it is also "available to all people and is not connected with the choice», it does not require reciprocity [8, p. 82]. Unlike love-eros, love-pity «considers another person in God's abandon, in the immersion in the world's darkness, in suffering». It is interesting to note, that according to M. Berdyaev, love-pity «in its pure form makes a man a slave», that is, deprives of freedom. It means that when a person is very fond of suffering and pitying another person, he/she thus forgets about the development of his/her own personality and responsibilities towards themselves [9, p. 33]. Therefore, in order for this love not to turn a man into a slave, it should be combined with love-eros.

In turn, P. Florensky singles out altruistic love-agape as one of the forms of love. It involves the recognition of the high value in the love object. The high values of such love include «the friendship of man and God, the eucharistic unity of Christians, selfless mercy, self-sacrifice for the sake of another person, freedom, compassion» [10, p. 117]. In altruistic love-agape, true-me and true-you are united in God with each other.

The latter is regarded as one of the fundamental values which has God as its source (M. Scheler); super-relevant valuable response (D. von Hildebrand); responsible mutual, caring, interpersonal attitude toward God (M. Buber); action (manifestation of human activity), «art» and fraternal love (E. Fromm); the form of being (for another) (E. Munier); emotional state and activity directed toward another person (J. Ortega y Gasset); manifestation of responsibility for all living things (A. Schweizer); the assertion of oneself and the other in freedom (J.-P. Sartre); a gift, a blessed love derived from God and aimed at its comprehension, a supreme manifestation of love (C. S. Lewis). The phenomena of love and mercy are closely linked, since they are directed toward another person through the prism of understanding it as a value, providing for some active behavior, sacrifice for the benefit of another person. Love and mercy also serve to affirm each other in existence, they are perfect forms of interpersonal relationships.

Thus, based on an understanding of ethics as the responsibility for all living things, A. Schweitzer points to the need to «do any possible good for another living being» [11, p. 223]. Hence, mercy is the duty of every human being, however, it is not only directed towards another person, but also towards all living things, which, similar to a person, strive for life. Accordingly, a person has no «rest» from good deeds. Moreover, the philosopher calls not just to perform good deeds, but also to seek for those who need help and compassion.

At the present stage of social development, the affirmation and development of the phenomenon of mercy on the conceptual level essentially correlate with the ideas of neo-Marxism and post-Marxism. In particular, representatives of neo-Marxism (G. Lukács, A. Gramsci, H. Marcuse, E. Bloch, H. Lefebvre, L. Althusser, W. Benjamin and others) emphasize that the subject and object appear to be interacting and interdependent factors of social cognition and activity. The medium of this reciprocity is the totality (the whole social practice at a certain historical stage of its development, society as a whole) [12, p. 23].

The phenomenon of mercy, being represented at the individual and social levels, is actively involved and is highly embodied in public practice (praxis) and appears as a manifestation of the subject's activity in relation to the object, their mutual influence. It is assumed that the subject (an individual) is actively involved in various forms of interaction with the environment surrounding $\mathrm{him} / \mathrm{her}$ (both at the level of society and nature). Being a «spiritual uprising against dehumanization», neo-Marxism offers a kind of social ethics of responsibility. A person should be perceived as «the totality of the inner world, the outer world and the social world». This very understanding of a person through the prism of his/her inclusion in the surrounding reality and the need to interact with others substantially correlate with the phenomenon of mercy, which is not limited only to the social aspect, but must continue to be realized in the natural one. Hence, it is possible to elucidate 
the understanding of human existence, which will allow achieving «reasonableness of the degree of activity, which is based on the realism and humanity of moral responsibility» [12, p. 33]. It is worth noting that the realization of mercy is one of the manifestations of moral responsibility of a person for his/her environment.

The ideas of neo-Marxists as to the subject of modern social-valuable transformations are complemented by representatives of post-Marxism, which in its essence contains a significant number of directions of socio-philosophical, political, economic and other discourses. In particular, taking into account the specifics of our research, it is expedient to dwell on the deliberative (E. Mandel, O. Lafontaine, I. Mészáros, F. Feher et al.) and the subsidiary (I. Mészáros, A. Gorz, R. Scholz, H. Reichelt, F. Shandl et al.) directions of post-Marxism. Among other things, deliberative post-Marxism (from the Latin deliberatio - discussion) proclaims democracy, first and foremost, communication that rationally forms the will of its participants, while «the development of a new society must be carried out as a free matter of liberated individuals» [13]. The indicated communication promotes the search of not only mutual understanding between individuals but also allows expanding the space of openness. It is worth pointing out that mercy also correlates with these ideas because it appears as a «form» of communication, a manifestation of openness towards other persons, their needs and interests. All this serves to deepen the integration of individuals within society.

Deliberative post-Marxism is combined with the subsidiary one, advocating for the expansion of the «social» sphere through the active participation of individuals in self-organizing self-government and the combination of their personal and general public interests. Within the framework of the considered directions of post-Marxism, the classical doctrine on the social revolution is preserved as «the need for joint actions of society and humanity» to solve their common problems. It is important to note that the basis of effective civic associations is the internal consistency of social orientations and valuable aspirations. Taking into consideration the example of mercy, these guidelines and values can include sacrifice, the pursuit of an activity for the benefit of others, assistance, etc.

\section{Results of research}

Taking into account the factor of multidisciplinarity of the phenomenon of mercy, its comprehension in the context of socio-philosophical analysis and social practice has received various interpretations, starting from ancient thinkers to the present stage of the philosophical thought development. Thus, at the present stage of development, the phenomenon of mercy substantially correlates with social and applied studies of neo-Marxism and post-Marxism. In this context, the author has elucidated that the phenomenon of mercy is actively involved and qualitatively embodied in public practice (praxis) and appears as a manifestation of the subject's activity in relation to the object, their mutual influence. In addition, mercy can be considered as a factor or element of social ethics of responsibility (an individual for the natural and social environment of his/her activity). Mercy can also serve as a factor in the active participation of individuals in self-organizing self-government, the formation of civil associations with the aim of implementing active transformations and quality changes in society.

\section{Conclusions}

1. Through the prism of the evolution of socio-philosophical thought, the phenomenon of mercy, regardless of its various interpretations, appears as an individual and social value.

2. Mercy appears as an act based on sacrifice, compassion and desire to participate in the life of another, aimed at perceiving another in integrity as a value, as well as for the benefit of another.

3. At the present stage of development in the context of social practice, mercy is perceived as a factor of the subject's activity in relation to the environment surrounding him, the active interaction between the subject and the object, the transformation of the latter, as well as the factor of the formation of civil society for the implementation of transformations in society. 
4. Mercy contains a powerful integrated potential, since it is able to overcome social exclusion and bring people together through active participation in their lives.

\section{References}

[1] Seneca L. A. On benefits. Seven books for Ebutio Liberal. Available at: http://ancientrome.ru/ antlitr/t.htm?a=1328203959

[2] Logunova, E. H. (2015). The concept of mercy in the writings of Augustine Aurelius. Modern approaches to the transformation of the endings of state regulation and management in socio-economic systems. Kursk, 222-225.

[3] Blessed, A. (1998). About the City of God. Ch. I-XIII. Vol. 3. Saint Petersburg: Aleteya, 595.

[4] Blessed, A. (2000). Confessions. Vol. 1. Saint Petersburg: Aleteya, 469-741.

[5] Kant, I. (1965). Fundamentals of metaphysics of morality. Vol. 4. Part 1. Moscow: Thought, $219-310$

[6] Kant, I. (1965). Metaphysics of manners. Vol. 4. Part 2. Moscow: Thought, 107-438.

[7] Feuerbach, L. (1995). The Essence of Christianity. Vol. 2. Moscow: Science, 5-320.

[8] Kovalchuk, Yu. (2015). Love for God as a creative personality path in the philosophy of love of Nikolai Berdyaev. Actual problems of philosophy and sociology, 4, 79-83.

[9] Riabinina, T. V. (1999). Dialectics of Love and Freedom in Erotic Philosophy of N. A. Berdyaev. Bulletin of the Moscow State Technical University. Moscow, 1, 29-34.

[10] Pavenkov, O. V. (2012). Metaphysics of love-agape in religious philosophy of P. A. Florensky. Bulletin of the Russian Christian Humanitarian Academy, 13 (4), 113-120.

[11] Schweitzer, A. (1992). Philosophy of Culture. Reverence for life. Moscow: Progress, 44-237.

[12] Zinchenko, V. V. (2013). Neo-Marxism and the transformation-value perspective of the left ideological and political discourse in the globalized modernity. Research publications, 2, 5-37.

[13] Zinchenko, V. V. (2016). Political ideas of post-Marxists. Political thought of XX - the beginning of the XXI centuries: methodological and doctrinal approaches. Vol. 1. Lviv: New World-2000, $280-326$. 